\title{
A Comparison Study on Knowledge and Use of Different ICT Tools of Farm Women of State Meghalaya
}

\author{
Das Puspita* and Sangma Ch. Nikrachi
}
AICRP-Home Science (Extension Education Component), College of Community Science, Central Agricultural University, Sangsanggre, Tura, Meghalaya, India

*Corresponding author

\section{A B S T R A C T}

\section{Keywords}

Knowledge of ICT tool, Use of ICT tool, Impact of ICT packages, Increased in adoption practices minimum

Article Info

Accepted:

15 December 2020

Available Online:

10 January 2021
Present study was undertaken to explore the level of knowledge of Farm Women on different aspects and use of selected ICT tools, to identify the knowledge about package content and to know the increase in adoption of practice minimum. The data was collected from 60 farm women groups during the year $2018-2019$. The results revealed that during pre-intervention 90 per cent each of the respondents had attained low level of knowledge on different aspects and use of selected ICT tool whereas after post-intervention 100 per cent each of the respondents had attained high level of knowledge on different aspects and use of selected ICT tool. While developing the packages and validate the test twenty numbers of text messages and valuable pictures related to packages were sent to them through text messages and WhatsApp messages whereas twelve numbers of videos on steps, importance, advantages and disadvantages on various packages were delivered through WhatsApp. According to their knowledge about package content during preintervention majority (91.67\%) of the farm women had attained low level of knowledge of the content of ICT whereas in post-intervention 81.67 per cent of the farm women had attained high level of knowledge of the content of ICT. As per their rate of adoption of packages that 53.33 per cent of the farm women were adopted the Vermicompost followed by 38.33 per cent of the farm women adopted Nutritional garden and 33.33 per cent of the farm women adopted Bee-Keeping after attending the hands on training programmes which was provided to them. The finding shows that the farm women were highly benefitted to which the package was disseminated to them.

\section{Introduction}

Information and Communications Technology (ICT) is technology that is used to handle communications processes such as telecommunications, broadcast media, intelligent building management systems, audiovisual processing and transmission systems, and network-based control and monitoring functions. ICT promises a fundamental change in all aspects of our lives, including knowledge dissemination, social interaction, economic and business practices, political engagement, media, education, health, leisure and entertainment. ICTs can play a significant role in combating rural and 
urban poverty and fostering sustainable development through creating information rich societies and supporting livelihoods. If ICTs are appropriately deployed and realize the differential needs of urban and rural people, they can become powerful tools of economic, social and political empowerment. Women face enormous challenges to use ICT for their own economic empowerment. Using and benefiting from ICT requires education, training, affordable access to the technology, information relevant to the user and a great amount of support to create an enabling environment. Access to affordable services and availability of infrastructure is without doubt a major requirement if ICTs are to be used for women's economic empowerment. The application of Information and Communication Technology (ICT) in agriculture is increasingly important. EAgriculture is an emerging field focusing on the enhancement of agricultural and rural development through improved information and communication processes. More specifically, e-Agriculture involves the conceptualization, design, development, evaluation and application of innovative ways to use information and communication technologies (ICT) in the rural domain, with a primary focus on agriculture. All stakeholders of agriculture production system need information and knowledge about these phases to manage them efficiently.

Information and communication technology in agriculture (ICT in agriculture), also known as e-agriculture, focuses on the enhancement of agricultural and rural development through improved information and communication processes. More specifically, e-agriculture involves the conceptualization, design, development, evaluation and application of innovative ways to use information and communication technologies (ICTs) in the rural domain, with a primary focus on agriculture. The use of mobile technologies as a tool of intervention in agriculture is becoming increasingly popular. Smartphone penetration enhances the multi-dimensional positive impact on sustainable poverty reduction and identify accessibility as the main challenge in harnessing the full potential (Silarszky et al., 2008) in agricultural space. The reach of smartphone even in rural areas extended the ICT services beyond simple voice or text messages. Several smartphone apps are available for agriculture, horticulture, animal husbandry and farm machinery.

The use of ICTs could have the potential in alleviating some of the barriers that women face in their daily mobility. The usage of mobile phones can for example include women and break constraints simply by a phone call or text message. ICT can offer many opportunities in remote and rural areas where mobility is restricted by breaking peoples way out of isolation and making it easier for them to access knowledge and productive resources (c.f. Sida 2015). Shekara, (2001) in his article reported that information dissemination in agriculture through ICT was cost effective, time saving and the speed of communication was high. As discussed by Mittal, et al., (2010), the rapid growth of mobile telephony and introduction of mobile-enabled information services provide solution to bridge the information gap in agriculture which limit the agricultural productivity.

Considering all the point a research study was undertaken with following objectives include to study the background profile of the respondents. To explore their level of knowledge about different aspects and use of selected ICT tool. To identify the knowledge about package content To know the increase in adoption of practice minimum

\section{Materials and Methods}

The study was carried out under AICRP- 
Home Science Project. The study was undertaken in the three villages of West Garo Hills, Meghalaya. The data was collected from 60 farm women groups of selected villages and the 60 farm women were selected randomly according to their availability and accessibility to mobile phones. The interview scheduled was prepared to explore their level of knowledge about different aspects and use of different ICT tools, to identify the knowledge about package content and to know the increase in adoption of practice minimum. The data was collected during $2018-2019$.

\section{Results and Discussion}

\section{Organization and promotion of Farm Women for enhanced use of ICT}

From table.1 indicates that six numbers of groups were formed with 10 respondents in each group from the three villages of Gambegre Block of West Garo Hills, Meghalaya. The number of total member at initial stage was sixty members whereas the number of present members was also sixty.

\section{Personal and socio-economic status of} respondents

\section{Age}

Fig. 1 indicates that large percentage $(65 \%)$ of the respondents belonged to young age (18$35 \mathrm{yrs}$.) and the least percentage $(5 \%)$ of the respondents belonged to upper middle age (51 years and above). The finding shows that majority of the respondents were from young age group.

\section{Education qualification}

It was found from fig. 2 that large percentage $(41.67 \%)$ of the respondents studied up to Class $\mathrm{X}$ followed by 20 percent were studied up to middle schools, 15 percent of the respondents can read and write whereas 6.66 per cent of the respondents were graduated and 1.67 per cent of the respondents were postgraduate. The finding shows that majority of the respondents have the basic knowledge of education.

\section{Marital status}

It is revealed from the fig. 3 that large percentages $(78.33 \%)$ of the respondents were married followed by 21.67 per cent of the respondents belonged to unmarried. This finding shows that majority of the respondents were married because in that respective area they get married at early age.

\section{Type of family}

It is revealed from the findings that entire respondents were belonged to nuclear family and it is an obvious picture to see that in the present scenario nuclear family system is prevailing in all parts of the country including North East states of Meghalaya.

\section{Occupation}

\section{Family occupation}

From figure 4 it is observed that 81.67 per cent of the respondents belonged to daily wage earner followed by 10 per cent of the respondents were engaged in government services and 5 per cent of the respondents belonged to farming.

The finding shows that majority of the respondents family member were predominantly from daily wage earner.

\section{Occupation of respondents}

From figure 5 it is observed that 98.33 per cent of the respondents belonged to farming followed by 1.67 per cent of the respondents were engaged in government services. The 
finding shows that majority of the respondents were engaged in farming to desire their day to day life.

\section{Land holding}

From fig 6 indicates that 40 per cent each of the respondents were belonged to marginal and small land holding to do their agriculture and livestock activities. The finding shows that selected farm women for the study were belonged to agrarian family because they do agriculture and allied activities for their livelihood security.

Knowledge and use of farm women group members in use of selected ICT tool for agriculture and allied sectors before and after the intervention programme

From the table 3.1 it indicates that during preintervention the respondents had no knowledge on functions of mobile phones (76.67\%), function of internet $(90 \%)$, utility of internet services (90\%), social media (90\%) and applications like agriculture and allied activities (100\%). Whereas during post intervention they had complete knowledge on function of mobile phones (100\%), function of internet $(81.67 \%)$, utility of internet services $(81.67 \%)$, social media $(100 \%)$ and applications like agriculture and allied activities (85\%) as well as some the respondents had partial knowledge on different ICT tools. The finding shows that during pre- intervention the respondents had no knowledge on different aspects of selected ICT tool. Similarly, after post intervention majority of the respondents had complete knowledge on different aspects of selected ICT tool because after pre-intervention different types of hands on trainings were organized to the selected respondents on importance of different aspects of selected ICT tools and the respondents were gained from the several trainings provided to them.
From the table 3.2 indicates that during preintervention majority $(90 \%)$ of the respondents had attained low knowledge on different aspects of selected ICT tool whereas after post- intervention 100 per cent of the respondents had attained high level of knowledge on different aspects of selected ICT tool. The finding shows that majority of the respondents were gained in knowledge to different aspects of selected ICT tool after attending several trainings conducted to them. So, the trainings were highly benefitted to the respondents.

From table 3.3 indicates that during preintervention the respondents had no knowledge on use of functions of mobile phones $(76.67 \%)$, function of internet (90\%), utility of internet services $(90 \%)$, social media (90\%) and applications like agriculture and allied activities (100\%). Whereas during post intervention they had complete knowledge on function of mobile phones (100\%), function of internet $(66.67 \%)$, utility of internet services $(66.67 \%)$, social media $(100 \%)$ and applications like agriculture and allied activities $(85 \%)$ as well as some of the respondents had partial knowledge on use of different ICT tools. The finding shows that during pre- intervention the respondents had no knowledge on use of selected ICT tool. Similarly, after post intervention majority of the respondents had complete knowledge on different aspects of selected ICT tool because after pre-intervention different types of hands on trainings were organized to the selected respondents on use of selected ICT tools and the respondents were attained knowledge and benefitted to them.

From the table 3.4 indicates that during preintervention majority $(90 \%)$ of the respondents had attained low knowledge level on use of selected ICT tool whereas after post- intervention 100 per cent of the 
respondents had attained high level of knowledge on use of selected ICT tool. The finding shows that majority of the respondents were attained knowledge level on use of selected ICT tool after attending several training programmes were conducted to them. So, the trainings provided to them were benefited.

\section{Development and testing of packages}

From the table 4.1 indicates that twenty numbers of text messages and valuable pictures related to packages were sending through messages and WhatsApp messages were delivered to them whereas twelve numbers of videos on steps, importance, advantages and disadvantages on various were delivered through WhatsApp.

Table.1 Farm women groups formed for enhancing the use of ICT

\begin{tabular}{|l|l|l|l|}
\hline No of groups & $\begin{array}{l}\text { Number of } \\
\text { villages }\end{array}$ & $\begin{array}{l}\text { No of members at } \\
\text { initial stage }\end{array}$ & No. of present members \\
\hline 6 Groups & 3 Villages & 60 & 60 \\
\hline
\end{tabular}

Table.2 Comparison of respondents knowledgeable about different aspects of selected ICT tool

\begin{tabular}{|l|l|l|l|l|l|l|}
\hline & \multicolumn{2}{|l|}{$\begin{array}{l}\text { Pre-intervention } \\
\text { Percentage of respondents }\end{array}$} & \multicolumn{2}{l|}{$\begin{array}{l}\text { Post intervention } \\
\text { Percentage of respondents }\end{array}$} \\
\cline { 2 - 7 } & $\begin{array}{l}\text { No knowledge } \\
(\%)\end{array}$ & $\begin{array}{l}\text { Partial } \\
\text { knowledge (\%) }\end{array}$ & $\begin{array}{l}\text { Complete } \\
\text { knowledge (\%) }\end{array}$ & $\begin{array}{l}\text { No } \\
\text { knowledge } \\
(\%)\end{array}$ & $\begin{array}{l}\text { Partial } \\
\text { knowledge } \\
(\%)\end{array}$ & $\begin{array}{l}\text { Complete } \\
\text { knowledge } \\
(\%)\end{array}$ \\
\hline Mobile functioning & 76.67 & 23.33 & - & - & - & 100 \\
\hline Functioning of internet & 90 & 10 & - & - & 18.33 & 81.67 \\
\hline $\begin{array}{l}\text { Utility services on } \\
\text { internet }\end{array}$ & 90 & 10 & - & - & 18.33 & 81.67 \\
\hline Social media & 90 & 10 & - & - & - & 100 \\
\hline $\begin{array}{l}\text { Applications } \\
\text { (Agriculture and allied } \\
\text { activities }\end{array}$ & 100 & - & - & - & 15 & 85 \\
\hline
\end{tabular}

Table.3 Comparison of respondents according to their level of knowledge about different aspects of selected ICT tool

\begin{tabular}{|l|l|l|l|l|}
\hline Intervention & \multicolumn{2}{|l|}{$\begin{array}{l}\text { Pre-intervention knowledge } \\
\text { Percentage of respondents }\end{array}$} & \multicolumn{2}{l|}{$\begin{array}{l}\text { Post intervention Knowledge } \\
\text { Percentage of respondents }\end{array}$} \\
\hline & F & $\%$ & F & $\%$ \\
\hline $\begin{array}{l}\text { Low knowledge } \\
(\mathbf{0 - 0 . 6 6 )}\end{array}$ & 54 & 90 & - & - \\
\hline $\begin{array}{l}\text { Medium knowledge } \\
(\mathbf{0 . 6 7 - 1 . 3 3 )}\end{array}$ & 6 & 10 & - & - \\
\hline $\begin{array}{l}\text { High } \\
(\mathbf{1 . 3 4 - 2 . 0 )}\end{array}$ & - & - & 60 & 100 \\
\hline
\end{tabular}


Table.4 Comparison of knowledge of respondents about use of selected ICT tool

\begin{tabular}{|l|l|l|l|l|l|l|}
\hline & \multicolumn{3}{|l|}{$\begin{array}{l}\text { Pre-intervention } \\
\text { Percentage of respondents }\end{array}$} & \multicolumn{2}{l|}{$\begin{array}{l}\text { Post intervention } \\
\text { Percentage of respondents }\end{array}$} \\
\hline & $\begin{array}{l}\text { No use } \\
(\mathbf{\% )}\end{array}$ & $\begin{array}{l}\text { Partial Use } \\
(\mathbf{\%})\end{array}$ & $\begin{array}{l}\text { Complete } \\
\text { Use (\%) }\end{array}$ & $\begin{array}{l}\text { No use } \\
(\mathbf{\%})\end{array}$ & $\begin{array}{l}\text { Partial Use } \\
(\%)\end{array}$ & $\begin{array}{l}\text { Complete } \\
\text { Use (\%) }\end{array}$ \\
\hline Mobile functioning & 76.67 & 23.33 & - & - & - & 100 \\
\hline Functioning of internet & 90 & 10 & - & - & 33.33 & 66.67 \\
\hline Utility services on internet & 90 & 10 & - & - & 33.33 & 66.67 \\
\hline Social media & 90 & 10 & - & - & - & 100 \\
\hline $\begin{array}{l}\text { Applications } \\
\text { (agriculture and allied } \\
\text { activities }\end{array}$ & 100 & - & - & - & 15 & 85 \\
\hline
\end{tabular}

Table.3.4 Comparison of respondents according to their level of use of different aspects of selected ICT tool

\begin{tabular}{|c|c|c|c|c|}
\hline \multirow[t]{2}{*}{ Intervention } & \multicolumn{2}{|c|}{$\begin{array}{l}\text { Pre-intervention } \\
\text { Percentage of respondents }\end{array}$} & \multicolumn{2}{|c|}{$\begin{array}{l}\text { Post intervention } \\
\text { Percentage of respondents }\end{array}$} \\
\hline & f & $\%$ & f & $\%$ \\
\hline $\begin{array}{l}\text { Low knowledge } \\
(0-0.66)\end{array}$ & 54 & 90 & - & - \\
\hline $\begin{array}{l}\text { Medium knowledge } \\
(0.67-1.33)\end{array}$ & 6 & 10 & - & - \\
\hline $\begin{array}{l}\text { High } \\
(1.34-2.0)\end{array}$ & - & - & 60 & 100 \\
\hline
\end{tabular}

Table.4.1 Packages developed, validated and tested for determining the effectiveness of ICT tool (Mobile) in delivery of practice/technology

\begin{tabular}{|c|c|}
\hline \multicolumn{2}{|c|}{ Name of the technology/practice: } \\
\hline \multicolumn{2}{|c|}{ Package content } \\
\hline No of text/text \& picture messages & No of videos \\
\hline 20 & 12 \\
\hline
\end{tabular}

Table.5.1 Comparison of respondent's knowledge about package content

\begin{tabular}{|l|l|l|l|l|l|l|}
\hline & \multicolumn{3}{|l|}{$\begin{array}{l}\text { Pre-intervention } \\
\text { Percentage of respondents }\end{array}$} & \multicolumn{2}{l|}{$\begin{array}{l}\text { Post intervention } \\
\text { Percentage of respondents }\end{array}$} \\
\hline & $\begin{array}{l}\text { No knowledge } \\
(\%)\end{array}$ & $\begin{array}{l}\text { Partial } \\
\text { knowledge } \\
(\%)\end{array}$ & $\begin{array}{l}\text { Complete } \\
\text { knowledge } \\
(\boldsymbol{\%})\end{array}$ & $\begin{array}{l}\text { No knowledge } \\
(\%)\end{array}$ & $\begin{array}{l}\text { Partial } \\
\text { knowledge } \\
(\%)\end{array}$ & $\begin{array}{l}\text { Complete } \\
\text { knowledge } \\
(\%)\end{array}$ \\
\hline Vermicompost Package & 80 & 20 & - & - & 21.67 & 78.33 \\
\hline $\begin{array}{l}\text { Nutritional Garden } \\
\text { Package }\end{array}$ & 86.67 & 13.33 & - & - & 15 & 85 \\
\hline Bee-Keeping Package & 100 & - & - & - & 25 & 75 \\
\hline $\begin{array}{l}\text { Mean percentage of the } \\
\text { package }\end{array}$ & 88.88 & 55.5 & - & - & 82.2 & 93.45 \\
\hline
\end{tabular}


Table.5.2 Comparison of respondents according to their level of knowledge of the content of ICT

\begin{tabular}{|l|c|c|c|c|}
\hline Intervention & \multicolumn{2}{l|}{$\begin{array}{l}\text { Pre-intervention } \\
\text { Percentage of respondents }\end{array}$} & \multicolumn{2}{l|}{$\begin{array}{l}\text { Post intervention } \\
\text { Percentage of respondents }\end{array}$} \\
\hline & f & \% & f & \% \\
\hline Low knowledge ( 0-0.66) & 55 & 91.67 & - & 18.33 \\
\hline Medium knowledge (0.67-1.33) & 5 & 8.33 & 11 & 81.67 \\
\hline $\begin{array}{l}\text { High } \\
(\mathbf{1 . 3 4 - 2 . 0 )}\end{array}$ & - & - & 49 & \\
\hline
\end{tabular}

Table.6.1 Perceived adoption of disseminated practice/technology after exposure to the practice/technology information

\begin{tabular}{|l|l|l|}
\hline \multirow{2}{*}{ Level of adoption } & \multicolumn{2}{|l|}{ Respondents } \\
\cline { 2 - 3 } & f & $\%$ \\
\hline No adoption & - & - \\
\hline Partial adoption & - & - \\
\hline Complete adoption & & \\
Vermicompost & 32 & 53.33 \\
Nutritional Garden & 23 & 38.33 \\
Bee Keeping & 20 & 33.33 \\
\hline
\end{tabular}
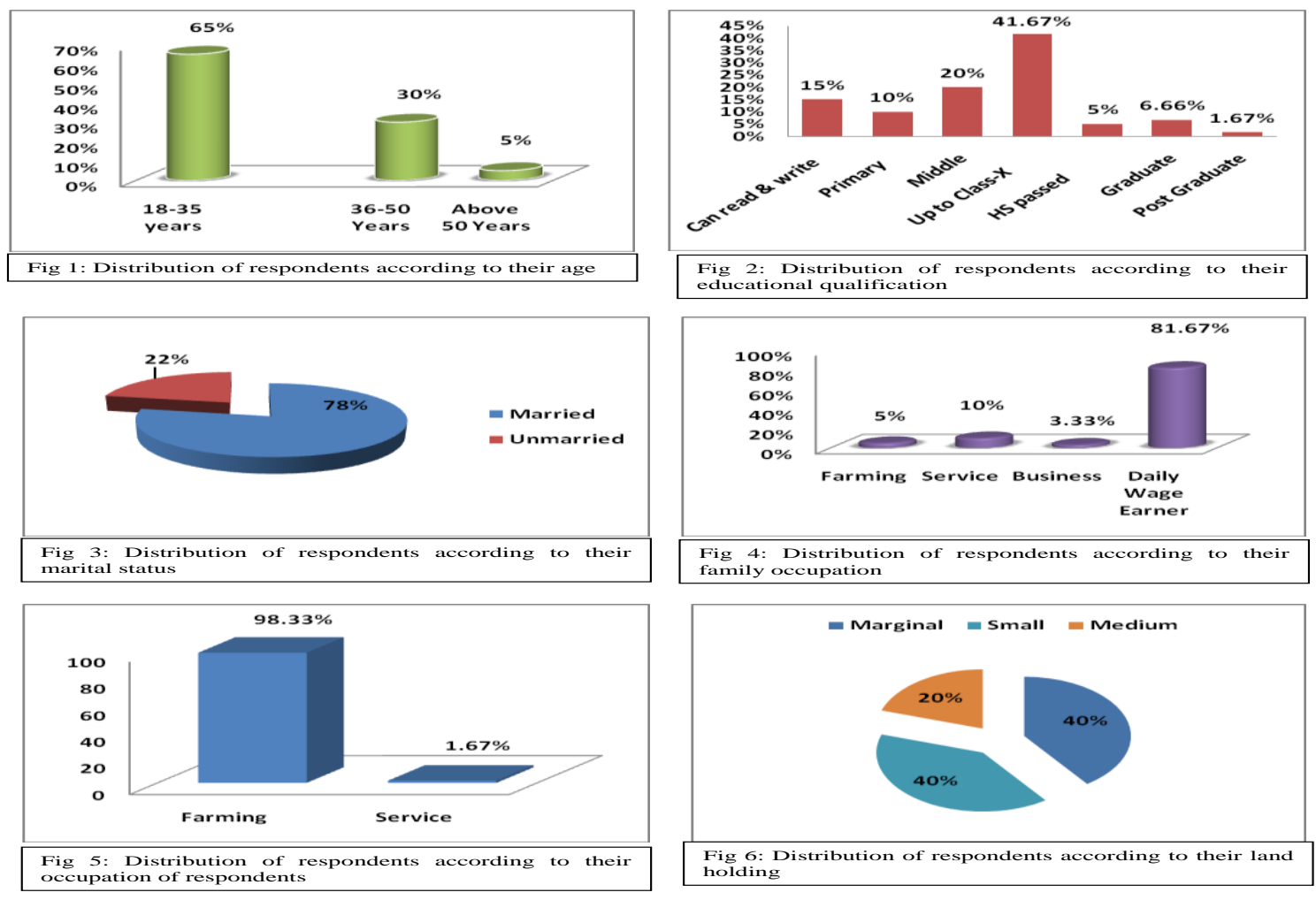


\section{Impact of ICT package}

From table 5.1 indicates that during preintervention the farm women had no knowledge about the package content of Beekeeping package (100\%) followed by nutritional garden package (86.67) and vermicompost package $(80 \%)$ whereas after post-intervention the farm women had complete knowledge about the package content of Nutritional garden package $(85 \%)$ followed by vermicompost package (78.33\%) and Bee-keeping package (75\%). The finding shows that after conducting the hands on training programmes on various topics as well as providing the materials like folder, leaflet and booklet which was written in local dialect provided much support to get more information.

From table 5.2 indicates that during preintervention majority (91.67\%) of the farm women had attained low level of knowledge of the content of ICT whereas after postintervention 81.67 per cent of the farm women had attained high level of knowledge of the content of ICT. The finding shows that majority of the farm women had attained high level of knowledge after attending the training programmes conducted on several topics and it was provided good support to the farm women to start up the enterprises on several ways of learning.

\section{Increase in adoption of practice minimum}

From the table 6.1 indicates that 53.33 per cent of the farm women were adopted the vermicompost followed by 38.33 per cent of the farm women adopted Nutritional garden and 33.33 per cent of the farm women adopted Bee-Keeping after attending the hands on training programmes which was provided to them. The finding shows that the farm women were highly benefitted to which the package was disseminated to them.
In conclusion the study shows that 60 farm women groups were formed from the selected villages of Gambegre Block of Meghalaya through a random sampling method. The three packages were developed to validate the programmes and the three packages were comprises of Vermicompost Package, Nutritional Garden Package and Bee-Keeping Package. To validate the packages several training programmes was conducted on various packages. During pre-intervention the farm women had attained low level of knowledge on different aspects of selected ICT tool, use of selected ICT tool and package of content. Whereas after postintervention their knowledge of level was high so the programmes on various packages were highly benefitted to them. Majority of the farm women were adopted the packages to start up their enterprises with help of training programmes and got a support from the AICRP-ECM Component of College of Community Science, Tura Meghalaya.

\section{References}

Swedish International Development Authority (Sida). (2015). Gender and ICT. Gender Tool Box Brief. [electronic] accessed at:

http://www.sida.se/contentassets/3a820 dbd152f4fca98bacde8a8101e15/gender -and-ict.pdf (collected 2017-02-20)

Singh K M, Kumar A and Singh R.K.P (2015). Role of Information and Communication Technologies in Indian Agriculture: An Overview. SSRN Electronic Journal

Mittal, S., Gandhi, S. and Tripathi, G. (2010). Socio-economic impact of mobile phones on Indian agriculture. New Delhi: Indian Council for Research on International Economic Relations, 53.

Shekara, C. (2001). Private extension: Indian way. Private Extension: Indian Experiences, National Institute of 
Agricultural Extension Management (MANAGE), Hyderabad, 25.

https://en.wikipedia.org/wiki/Information_and _communications_technology_in_agric ulture https://www.techopedia.com/definition/24152 /information-and-communicationstechnology-ict

\section{How to cite this article:}

Das Puspita and Sangma Ch. Nikrachi. 2021. A Comparison Study on Knowledge and Use of Different ICT Tools of Farm Women of State Meghalaya. Int.J.Curr.Microbiol.App.Sci. 10(01): 2663-2671. doi: https://doi.org/10.20546/ijcmas.2021.1001.309 